\title{
Evidence-Based Physical Therapy for Anterior Cruciate Ligament Injury: Literature Review
}

Hyoung won Lim

Department of Physical Therapy, Dankook University, Cheonan, Korea

Most athletes with anterior cruciate ligament $(\mathrm{ACL})$ ruptures undergo a surgical $\mathrm{ACL}$ reconstruction $(\mathrm{ACLR})$ and rehabilitation. On the other hand, controversy still exists because neither a reconstruction nor rehabilitation have been proven to be superior in the management of ACL injury. This study reviewed the success rates of interventions to provide recommendations for the optimal management after an ACL injury. One of the most important considerations after an ACL injury is the timing and type of intervention. At the early stages, which involve the loss of volume and strength of quadriceps femoral muscle, weight bearing (closed kinetic chain) exercises with pain management followed by high velocity resistance exercises in an open kinetic chain environment are recommended to improve the quadriceps function. After that, it is important to apply intensive isokinetic exercise with a lower extension rate. In this case, it is important to apply overload to the muscles and to simultaneously lead the co-contraction of the hamstrings. Standards are essential because the timing and type of interventions are crucial to prevent re-injury and complications, such as osteoarthritis, as well as to confirm the successful outcome of the treatment. Different interventions recommended for ACL damage have yet to reach consensus. Further studies will be needed to observe the effects of the intervention through multidisciplinary approaches.

Keywords: ACL rehabilitation, Evidence- based physical therapy, Muscle strength

\section{서 론}

앞십자인대(anterior cruciate ligament, ACL)는 정강뼈 평탄부(tibial plateau)의 앞 융기사이 영역 (anterior intercondylar area)에 있는 패인 부위를 따라 부착되며, 가쪽 넙다리뼈 관절융기의 안쪽면에 부착하 기 위하여 뒤쪽, 위쪽, 그리고 가쪽 방향을 향해 비스듬히 주행한다. $\mathrm{ACL}$ 손상의 약 $70 \%$ 는 한발씩 끊어서 옆으로 걷기(sidestep cutting), 비 틀림(pivoting), 축과 관상면에서 다관절 움직임을 포함하는 발의 위 치와 같은 갑작스러운 감속이나 방향 변화로 발과 지면 접지에서 비 틀림 움직임 시 자신의 움직임 때문에 자연적으로 발생하는 비접촉 성 손상으로 일어난다. ${ }^{2-4}$ 비접촉성 ACL 손상을 일으키는 원인으로 는 좋지 않은 하지의 정렬, 인대의 패임이나 좌우로 벌어진 형태, 불충 분한 근육 보호나 신경근육 조절 등으로 발생된다. ${ }^{5} \mathrm{ACL}$ 의 주요기능 은 넙다리에 대한 정강뼈의 전방 병진운동(anterior translation)의 제 한이다. 즉, 넙다리 뼈가 고정되었을 때 정강뼈가 앞으로 밀려나는 것 을 막으며, 앞쪽 전단력(shearing force)에 대한 저항의 대부분을 제공

Received Mar 18, 2019 Revised Apr 16, 2019

Accepted Apr 19, 2019

Corresponding author Hyoung-won Lim

E-mail movt12@hanmail.net
한다. ${ }^{6} \mathrm{ACL}$ 손상은 상당히 일반적이며, 미국에서는 매년 약 25 만명 정도가 $\mathrm{ACL}$ 손상으로 고통 받는다. ${ }^{78}$ 이것은 전체인구에서 3,000 명당 1 명에 해당하며, ${ }^{7}$ 치료 비용으로는 연간 10 억 달러 이상이 지출된다. 이러한 손상은 스포츠와 운동 중에 흔히 발생하며, $\mathrm{ACL}$ 손상 관리에 대한 임상 치료 패턴은 전세계적으로 다르다. ${ }^{9} \mathrm{ACL}$ 손상은 무릎주변 부의 불안정성을 유발하고, 이로 인해 이차적인 퇴행성관절염, 넙다 리 근육의 위축, 근력약화 등을 초래 한다.1,10-13

다수의 비접촉성 $\mathrm{ACL}$ 손상 예방 프로그램은 유연성, 고유수용성 감각, 민첩성, 플라이오메트릭 및 근력강화 훈련의 결합을 통한 신경 근 조절 개선에 초점이 맞추어 지고 있다. ${ }^{5}$ 이러한 프로그램은 무릎 밖굽이 모멘트(knee valgus moments), 착지 과제 시 최대 수직 지면 반 발력 감소, 엉덩.무릎 관절 굽힘 증가, 동적 균형 개선과 같은 운동 위 험 요소에 긍정적인 변화를 나타냈다. ${ }^{5}$ 그러나, Yoo 등 ${ }^{14}$ 은 $\mathrm{ACL}$ 손상 예방 프로그램인 신경근 훈련(neuromuscular training)에서 균형훈련 보다 플라이오메트릭과 근력강화가 더 중요한 요소라고 하였으며, 이 와 유사하게 균형훈련 효과에 대한 근거를 찾지 못한 보고가 있었
Copylight (C2019 The Korean Society of Physical Therapy

This is an Open Access article distribute under the terms of the Creative Commons Attribution Non-commercial License (Http:// creativecommons.org/license/by-nc/4.0.) which permits unrestricted non-commercial use, distribution, and reproduction in any medium, provided the original work is properly cited. 
다. ${ }^{15}$ 다른 연구에서는 이와 반대로 균형훈련의 긍정적인 효과를 보 고한상충된 연구 결과 보고가 있었다. ${ }^{16}$

최근 $\mathrm{ACL}$ 손상 환자는 수술적 중재 유무와 상관없이 근거중심재 활(evidence-based rehabilita- tion) 수행의 중요성과 이에 대한 관심이 증대되고 있다. 이와 같은 맥락에서, 근거중심 재활이란 용어는 근골 격계 질환 중재의 핵심요소라 할 수 있는 운동치료를 말하며, 운동치 료는 유익성의 과학적인 증거를 가진 다른 방식으로 증가시킬 수 있 다. 운동치료에는 저항훈련, 신경근 운동, 높은 수준의 역동적인 기능 적 과제와 특정 스포츠 훈련과 같은 구성요소가 포함된다. ${ }^{9}$

그러나, ACL 손상에 대한 예방 프로그램의 효과, 근력증가를 위한 최적의 방법, 수술 유무에 따른 물리치료 중재효과, 그리고 신경근 훈 련의 효과에 대한 합의는 매우 부족하다. 따라서 본 연구에서는 ACL 손상 환자의 관리에서 성공율이 높은 중재방법을 문헌고찰을 통해 조사하고 이를 통해 효과적인 중재방법과 손상 후 상담을 위한 권고 안을 제시하고자한다.

\section{본 론}

\section{1. $\mathrm{ACL}$ 손상기전 및 생체역학적 관점}

$\mathrm{ACL}$ 의 손상을 유발하는 기전들은 매우 빠르게 일어나기 때문에 흔 히 예측할 수 없으며, 손상 시점에서 무릎에 적용된 정확한 방향과 유력한 방향이 항상 명확한 것은 아니다. 스포츠와 관련된 ACL 손 상의 약 $70 \%$ 는 비접촉성 손상으로 점프해서 착지할 때 혹은 한쪽 다 리를 고정한 상태에서 빠르고 강력한 감속이나 방향전환 시 발생된 다. 또한 해부학적인 위험 요인과 관련하여 성별 간에 존재하는 많은 차이가 있다. 일반적으로 여성은 남성에 비해 증가된 넙다리뼈 앞굽 음(femoral anteversion), Q각, 과도한 정강뼈 비틀림(tibial torsion)과 목 말 밑 관절 엎침(subtalar pronation)을 보인다. 여성은 남성보다 ACL 손상을 입을 가능성이 2-8배 더 높게 보고 되었으며, 이러한 이유는 해부학적 그리고 호르몬의 차이와 함께 신경근 패턴이 사춘기 이후 에 나뉘기 때문이라고 설명하였다.14,17-21 이러한 요인들 중 꺾임/비틀 림 움직임 시 기능적인 불안정성을 초래하는 불충분한 신경근 조절 은 수정 가능하며 ACL 손상을 줄이는데 효과적이라고 하였다. ${ }^{16}$

무릎관절 폄 운동 시 과도한 정강뼈 앞 병진운동(anterior tibial translation, ATT)은 반월판과 무릎 안쪽에 있는 다른 수동적인 구조 들의 손상을 일으킬 수 있다. ${ }^{6}$ 넙다리뒤근(hamstring)의 동시수축 은 ACL이 손상된 무릎에 ATT를 줄일 수 있다.22-33 넙다리뒤근육은 정강 뼈의 후방에 부착하고 있기 때문에 ATT를 줄일 수 있으며, 따라서 하 퇴를 후방으로 끌어당기는데 적용될 수 있다. 일정량 의 넙다리뒤근 근활성화는 얼마나 빠르게 무릎을 펴는 것과 상관없이 손상된 ACL 의 무릎을 안정 화 시키는데 필요하다. ${ }^{6} \mathrm{ACL}$ 이 손상된 무릎을 안정시
키기 위해 필요한 넙다리뒤근의 동시수축 정도는 폄 속도와 관련하 여 반비례한다. ${ }^{6}$ 이것은 넙다리네갈래근의 힘-속도 상관관계(forcevelocity relationship)로 설명할 수 있다. 또한 이러한 반비례 관계는 넙 다리네갈래근육에 의해 발달된 힘이 속도로 기능하기 때문에 폄 속 도가 증가할수록 ATT는 감소한다고 설명할 수 있다. 넙다리뒤 근육 동시수축은 낮은 저항 폄 운동(예, 고속에서 무릎 폄)보다 ATT 감소 에 더 효과적인 것으로 보고되었다. ${ }^{6}$ 폄 속도가 증가함에 따라, 넙다 리네갈래근육의 수축력은 증가하며, 넙다리네갈래근 육 힘줄에 전 송되는 합력은 감소되며, 하퇴에 적용된 전방 전단력(anterior shear force)은 낮아진 다. ${ }^{34}$

넙다리뒤근육에 의해 제공되어지는 후방 전단력은 무릎뼈 힘줄 힘과 정강넙다리 압박력(patellar tendon force and tibiofemoral compressive force)에 의해 제공된 전방 전단력을 압도하기 때문에 넙다리 뒤근육의 활성도가 증가할수록 최대 ATT는 감소한다. ${ }^{6}$ 선행 연구에 서 느린 속도의 등속성 운동방법은 빠른 속도보다 더 높은 ATT 값을 생성하는 것으로 나타났다. ${ }^{34}$ 임상적으로, 이 소견은 고속이나 낮은 저항 폄 운동은 적어도 충분한 이식의 성숙과 근력이 발생할 때까지 는 ACL 재건술 무릎에 대한 재활훈련프로그램의 초기단계 동안에 사용될 수 있다는 것을 시사한다. ATT를 감소시킴으로써 관절의 안 정성을 높일 수 있도록 고안된 등속성 폄 프로토콜에서 넙다리 뒤근 육 동시수축은 $\mathrm{ACL}$ 손상 무릎의 보존적인 치료를 위한 낮은 저항 폄 운동보다 더 효과적 이었다. ${ }^{6}$ 낮은 속도가 더 높은 넙다리네갈래근육 의 근력을 내는 것을 감안할 때, 이러한 소견은 넙다리네갈래근육 근 력강화를 위해서는 낮은 폄 속도로 운동하는 것이 더 유리하다는 것 을 시사 하며, 넙다리뒤근육이 허용 한도 내에서 ATT를 유지하기 위 해 충분한 힘으로 수축할 수 있게 해 야 한다. ${ }^{6}$ 마지막으로, 최대 ATT 는 폄 속도가 증가함에 따라 감소하지만, 어느 정도의 넙다리뒤 근육 동시수축은 항상 $\mathrm{ACL}$ 손상 무릎 모델을 안정시키기 위해 필요한 것 으로 나타났다. 재활 프로그램에 허벅지 근력강화를 위해 부가적으 로 등속성 운동을 포함시킨다면, $\mathrm{ACL}$ 손상 환자는 이 운동 동안에 자신의 넙다리뒤근육을 동시수축 할 수 있게 하는 것이 중요할 것이 다. 그렇지 않으면 시간이 갈수록 과도한 ATT는 관절에 더 변성을 초 래하여 반월판 및 다른 수동 구조들에 손상을 일으킬 수 있을 것이 다. ${ }^{6}$ 따라서 $\mathrm{ACL}$ 손상 무릎의 안정성 증진을 위한 근력강화 운동에 서 넙다리 뒤근육의 작용과 등속성 운동 속도를 고려할 필요가 있을 것으로 사료된다.

\section{2. 예방 프로그램}

$\mathrm{ACL}$ 손상 환자에서 균형 및 정적 스트레칭 등의 예방 프로그램들은 부상의 위험을 감소시키는 것으로 나타났다. . $^{1435-37}$ 이러한 프로그램 들은 축구 선수에서 적절한 점프-착지 기술을 향상시키기 위해서 근 
력강화, 신장, 민첩성, 균형 그리고 피드백 훈련 같은 중재결합이 따라 야한다. ${ }^{38}$

Yoo 등슨 여성 운동 선수에서 ACL 손상 예방에 신경근 훈련의 효과의 메타분석 결과 균형 보다 플라이오메트릭과 근력강화 프로 그램이 효과적이라고 보고했으며, 이와 유사하게 ACL 예방 프로그램 으로 밸런스 보드를 사용한 연구에서 균형 훈련 효과에 대한 근거를 찾지 못하였다. ${ }^{15}$ 반면 Myer 등 ${ }^{16}$ 은 ACL 손상 예방 프로그램인 신경근 훈련(plyometric versus dynamic stabilization and balance training) 적용 으로 하지의 생체역학적 움직임 변경에 미치는 영향을 조사하였다. 연구결과 플라이오메트릭과 균형훈련 모두 하지의 밖굽이를 감소시 킨다고 하였다. 또한, 플라이오 메트릭 훈련은 수직 점프 착지 시 초기 접지기(initial contact) 무릎 굽힘과 최대 무릎 굽힘을 증가시키는 반 면, 균형훈련은 한발로 착지 시 최대 무릎 굽힘을 증가시킨다고 하였 다. Taylor 등 38 은 상기 연구에서의 균형훈련 프로토콜을 면밀히 분석 한 결과 다른 균형훈련 구성요소와 비교했을 때 상당히 높은 지속시 간과 강도를 사용했음을 발견했다. 시각 및 구두 명령을 포함한 다양 한 유형의 피드백은 $\mathrm{ACL}$ 손상과 관련된 비정상적인 생체역학을 감소 시키는 것으로 나타났다. ${ }^{39-41}$ 이러한 균형 훈련에 대한 상이한 결과로 는 각기 다른 적용시간과 강도의 적용 그리고 치료사의 피드백이 좀 더 역동적이고 기능적인 활동에 영향을 줄 수 있기 때문이라고 하였 다.16,38 따라서 향후 연구에서는 중재 적용 시 일관성 있게 적용하여 연구결과를 객관적으로 비교할 수 있도록 하여야 할 것이다.

\section{3. 닫힌 대 열린운동사슬에 따른 넙다리 근력강화를 위한 포괄적인 재활프로그램}

$\mathrm{ACL}$ 손상 후 넙다리네갈래근육 근력 증가를 위한 최적의 재활요법 에 대한 합의가 없다. ${ }^{42}$ 일반적으로 열린사슬운동(open kinetic chain exercise, $\mathrm{OKC}$ )은 관절의 느슨함과 $\mathrm{ATT}$ 의 증가 뿐만 아니라 $\mathrm{ACL}$ 의 변 형을 증가시킨다고 알려져 있어 $\mathrm{ACL}$ 손상 환자에게는 금기시 되고 있는 방법 이다. ${ }^{43}$ 직관적으로, 닫힌사슬운동(closed kinetic chain exercise, $\mathrm{CKC}$ )의 경우 원위에 고정된 발이 $\mathrm{OKC}$ 의 비고정 발보다 안전하 다고 생각한다. ${ }^{4}$ 이러한 입장은 $\mathrm{OKC}$ 운동 중 정강뼈 전방전위 검사 (anterior tibial displacement test)를 사용하여 더 큰 관절 이완이 있음 을 보여준 Yack 등 ${ }^{45}$ 의 연구를 따른 것이다. 많은 물리치료사들은 $\mathrm{OKC}$ 운동이 $\mathrm{CKC}$ 운동 보다 $\mathrm{ACL}$ 과 무릎넙다리관절에 더 큰 변형을 가한다고 믿는다. ${ }^{46}$ 그러나, $\mathrm{ACL}$ 결손을 가진 환자에서 $\mathrm{CKC}$ vs $\mathrm{OKC}$ 에 따른 넙다리 근력강화의 효과를 조사한 연구 결과 $\mathrm{OKC}$ 그룹에서 중재 후 유의하게 큰 등속성 넙다리 근력을 보인 반면 넙다리뒤근의 근력, 정적 및 동적 병진운동 그리고 기능적인 결과는 그룹간 비슷한 결과를 나타냈다. ${ }^{46}$ 또 다른 연구에서는 CKC vs OKC 중재 효과를 비 교한 체계적 고찰 결과 그룹간 유의한 차이가 없는 것으로 나타났
다. ${ }^{46}$ 따라서 $\mathrm{ACL}$ 혹은 재건술(anterior cruciate ligament reconstruction, ACLR) 후 OKC와 CKC 중재는 모두 유용할 수는 있지만 어느 쪽이 다른 쪽보다 우월하다고 말할 수 없다.

대부분의 ACL 재활 프로토콜에서 체중부하 운동이 강조됨에도 불구하고, 넙다리네갈래근육의 근력 강화 훈련이나 평가를 위해 등 속성 무릎 폄 운동의 사용은 손상 및 수술 후 8 주에서 6 개월 까지 일 반적이다. ${ }^{47-50} \mathrm{Gerber}$ 등 51 은 ACLR 후 3 주 후부터 시행된 15 주간의 집 중된 편심성 저항 훈 련 프로그램은 ACLR 후 1년 동안 표준 재활과 비교해서 넙다리네갈래근육과 큰 볼기근의 근육 량과 넙다리네갈래 근육의 근력, 도약거리 등에서 증가를 보였다. 생체역학적 관점과 등 속성 운동 의 효과를 고려할 때 등속성 운동 시 ACL이 손상된 무릎 관절의 안정성에 넙다리뒤근의 작용과 등속성 운동 속도의 영향을 결정하는 것은 중요하다고 하였다. ${ }^{6}$ 이미 살펴 본 것처럼 넙다리네 갈 래 근육의 근력을 강화하기 위해서는 중재 초기에는 빠른 속도의 등 속성 운동을 적용하는 것이 좋다. 따라서 $\mathrm{ACL}$ 손상 초기 이후에는 적극적인 근력강화를 위해서 낮은 폄 속도에서 집중적인 등속성 운 동을 하는 것이 바람직하며, 이때 넙다리뒤근육을 동시 수축할 수 있 게 하는 것이 중요하다.

\section{4. 수술 후 중재 효과}

북미에서는 $\mathrm{ACL}$ 파열이 된 운동선수나 사람들의 대부분은 ACLR을 받는다.951 ACLR 후 근육량과 근력의 회복은 지속적으로 재활의 과 제가 되고 있다.52 이전 연구에서 침범된 넙다리 근육의 위축 크기가 ACLR 후 3주 만에 25-30\%까지 도달했다고 보고되었다.52 ACLR의 주 된 촉진요소는 환자를 이전의 기능적인 수준으로 복귀시키는 것이 며, 전반적인 관절 건강을 회복 시키는 것이다. 이러한 목표를 달성하 기 위하여, 환자들은 초기 체중부하, 관절가동범위를 증가시키 는 운 동, 근력, 고유수용감각 및 균형 뿐만 아니라 기능적인 운동을 포함 하는 광범위한 ACLR 후 재활을 받아야 한다.53

점진적인 높은 힘의 편심성 저항의 적용은 ACLR을 받은 개인이나 다양한 집단에서 근육량과 근력을 안전하게 증가시키는 것으로 밝 혀진 중재방법의 하나이다.54-59 이러한 편심성 저항 중재는 높은 근력 을 유도하고 특히, 근육의 과부하를 생성하기 위해 고안되었다.51,52 집 중적인 편심성 저항훈련으로 근육량과 근력, 도약 거리의 개선을 보 고한 연구가 있었다. ${ }^{51}$ 이와 반대로 조기에 ACLR을 한 환자와 재활로 만 관리된 환자, 그리고 초기 재활로 관리를 받다가 지연된 ACLR을 받은 환자 사이에서 자기 보고식 신체활동 수준, 반월판 수술률, 증 상, 삶의 질과 방사선상 관절변화에서 그룹간 결과 차이가 없었다.60,61 또 다른 연구에서는 근력 및 신경근 훈련으로 관리된 $\mathrm{ACL}$ 파열 환자 혹은 ACLR 후 재활의 결과를 비교한 결과 비슷한 기능적인 그리고 방사선적인 결과를 얻었으나, ACLR 그룹은 더 많은 관절 삼출물, 더 
나은 자가 보고식 무릎 기능, 그리고 더 낮은 자가 보고식 공포를 가 지고 있었다. ${ }^{62}$ Kovalak 등 63은 신경근 훈련으로만 관리되거나 ACLR 로 관리된 운동 선수들 사이에 규칙적인 신체활동, 8 년 간의 무릎 기 능, 근력 또는 삶의 질 간의 차이가 없었다. Van Yperen 등 ${ }^{64}$ 은 체계적 인 재활 및 생활 습관 수정으로 관리된 ACL 파열 환자나 ACLR로만 관리된 환자의 20년 결과를 비교하여 ACLR 그룹이 무릎 이완이 적 다는 사실에도 불구하고, 반월판 절제율, 방사선상 골관절염, 그리고 기능적인 결과에서 그룹간 차이가 없는 것으로 나타났다.

ACLR 후 자주 관찰되어지는 지속적인 근육량 및 근력 소실에도 불구하고 일부 재활프로그램 들은 조기 저항 운동을 강조하지 않는 다. 다른 재활프로그램들은 이식부위와 관절 안전에 대한 우려 때문 에 저항운동을 과소평가하는 것으로 생각된다. 그러나, 이러한 요인 들은 ACLR 후 첫 3개월 동안 보고된 좌우 넙다리네갈래근 근육량 및 근력 소실의 $20-30 \%$ 와 1 년에 약 $10 \%$ 의 근력 소실에 기여할 수 있다. ${ }^{51}$

ACLR 훈련 전부터 1년까지 추적관찰을 한 연구에서 넙다리근육 뿐만 아니라 두덩 정강근 (gracilis muscle) 근육량의 현저한 감소가 관 찰되었다. 두덩 정강근의 근육량은 무릎뼈 힘줄을 이식한 ACLR 환 자에게는 상대적으로 변화가 없었으나, 반힘줄근-두덩정강근 힘줄 을 이식한 ACLR 환자에서는 현저하게 감소했다.52 ACLR 후 반월판과 연골의 상태가 치료결과에 영향을 준다는 증거가 있다.65-67 Claes 등 68 은 ACLR만 한 환자보다 ACLR 과 함께 부분적인 반월판 절개술을 받 은 후 환자의 골관절염 비율이 유의하게 높게 나타났으며, 이는 반월 판의 완전한 모양 유무가 ACL이 손상된 무릎에서 골관절염 발달의 핵심 요소임을 입증한 연구이다. 다수의 최근의 연구 결과에서 ACL 파열된 후 개인이 재활 혹은 ACLR을 받은 경우와 상관없이 무릎기 능, 활동수준, 삶의 질, 그리고 방사선상 골관절염 유병률 등에서 유 의한 결과 차이가 없음을 알 수 있었다. 생체역학 연구들은 만성 $\mathrm{ACL}$ 결손 무릎에서 앞 정강뼈 병진운동이 반월판 뒤뿔에 스트레스 집중을 일으키는 것으로 나타났다.6977 따라서 ACL 파열 후 만성적인 전방 회전 불안정성이 2 차 반월판 손상을 발달시키는 위험인자로 생 각된다. ${ }^{72}$

Gerber 드ㅇㅣㅣ은 저항훈련의 점진적이며 개별화된 특성을 통해 이식 부위의 안정성을 유지하면서 넙다리네갈래 근육의 근육량 및 기능 이 향상됨을 보고하였다. 이러한 소견들은 ACLR 후 초기 재 활 단계 에서 점진적인 저항훈련의 중요성과 나아가 고강도 편심성 운동 중재 가 포괄적인 재활 프 로그램 일환으로 실행 가능한 선택임을 시사한 다. ${ }^{51}$

또 다른 이전 연구의 보고에 의하면 ACLR 후 신체활동 복귀 첫 해 에 동측이나 반대측 지절에 2 차 $\mathrm{ACL}$ 손상을 입을 가능성이 15 배 높 다고 보고하였다. ${ }^{22}$ 최근 복귀 후 최대 2 개월까지 재손상율을 기록한 보고에 따르면 인구의 $9 \%$ 가 수술 부위를 다시 다쳤으며, $20.5 \%$ 가 반
대측 $\mathrm{ACL}$ 의 파열을 보고하였다. ${ }^{73}$ 이처럼 $\mathrm{ACL}$ 혹은 $\mathrm{ACLR}$ 후 재손상 이나 다른 골관절염과 같은 합병증을 예방하려면 치료의 성공적인 결과를 확인하기 위한 기준이 필요하다. Lynch 등 74 은 ACL 손상 및 ACLR 후 성공적인 결과와 관련하여 1,179 명의 스포츠 의학 전문가로 부터 합의 기준을 확립 했다. 성공적인 결과의 합의는 재손상이나 재 발한 무릎 꺾임(giving way)이 없으며, 관절 삼출물이 없으며, 대칭적 인 넙다리 근력, 회복된 활동 수준 및 기능, 손상 전 스포츠 활동으로 복귀하는 것 으로 밝혀졌다. ${ }^{74}$

그러므로 ACL 파열 및 ACLR 후 재활은 개별화 및 치료의 성공적 인 합의 기준을 기반으로 하여야 하며, 재활과정의 통합된 부분으로 스포츠와 일상의 활동으로 점진적으로 복귀하여야 한다. ACL 손상 으로 인한 무릎 부상은 장기간의 결과와 관련이 있으며, 손상된 ACL 환자를 관리할 때 후속의 무릎 부상 위험을 줄이는 것이 핵심 우선 순위가 되어야 한다.75

또한, 후속부상의 위험을 줄이려면 ACLR을 한 피보팅 스포츠(pivoting sports) 선수들은 스포츠 복귀를 위한 기능적인 기준을 통과해 야 하고 수술 후 최소 9 개월 동안 전체 참여를 지연해야만 한다. ${ }^{9}$

수술 후 중재로는 특히, 첫 3개월 동안에는 고강도 편심성 저항을 적용하여 근육량과 근력을 안전하게 증가시켜야 하고, 치료의 성공 적인 결과를 확인하는 기준을 엄격히 지킨다면 높은 재발률을 방지 할 수 있을 것이다. 이러한 체계적인 적용은 수술 후 중재 효과를 극 대화시킬 수 있을 것으로 기대된다.

\section{5. 고려사항들}

그 밖에 ACL 손상 혹은 ACLR 후 고려하여야 할 사항들로는 특히 초 기 통증관리가 중요하며, 안정적이며 정상적인 보행 요소와 건강한 그룹이나 비 손상측과 비교하여 다른 근활성도, 그리고 제한된 발등 굽힘과 밀접한 관련성을 갖는 점이다.

\section{통증}

ACLR 후 통증 관리에 대한 무작위 대조군 연구에 대한 체계적 고찰 결과 국소신경차단 및 관절내 주사(regional nerve blocks \& intra-articular injections)는 모두 효과적이라고 하였다. ${ }^{7}$ 또한 냉치료와 압박 (cryotherapy-compression)은 관절내 온도를 충분히 감소시킴으로써 통증감소에 도움이 된다고 하였으며, 조기 가동(mobilization) 역시 통증을 줄일 수 있다고 하였다. ${ }^{76}$

\section{보행}

ACLR (patellar tendon 과 hamstring tendon)을 받은 환자와 건강한 대 조군에게 보행을 비교하고 평가한 연구에서 ACL 손상 그룹 모두에 서 수술 후 3개월에 넙다리근 회피 패턴(quadriceps avoidance pattern) 
을 보였으며, ACL 수술 그룹에서 시공간변인(spatio-temporal parameters)과 무릎 굽힘 각도는 이미 수술 후 6개월에 보행 시 ACL 손상 지 절에서 정상패턴 으로 회복했다. ${ }^{22}$ 그러나, 각 가속도(angular acceleration)는 수술 후 9 개월에야 건강한 대조군의 값과 통계적으로 유의한 차이가 없었다. 15 도 경사 트레드밀에서 굴곡 각 가속도는 넙다리뒤 근 힘줄 이식 그룹보다 유의하게 작았다. 폄에 대한 각 가속도는 수술 후 6개월에 무릎뼈 힘줄 이식 그룹보다 유의하게 작았다.7

Sole G 등 78은 ACLR과 ACLR을 받지 않은 환자에서 20년 후 계단 내 려가기 시 무릎 운동형상 학을 각기 세 그룹 즉, ACLR 그룹, 물리치료 로만 관리된 ACL 손상환자(평균연령 23.5세), 그리고 대조군을 대상 으로 보행 분석을 하였다. 계단 하강 시 두 그룹 모두 대조군에 비해 운동학적 변인보다 시간 변인에서 더 많은 차이를 보였다. ACLR과 ACL-PT그룹 모두 대조군에 비해 보행속도는 느리게 나타났으며, 대 조군과 비교해서 물리치료만 받은 그룹에서 손상측이나 정상 측의 초기 접지기(initial contact)시 상당히 적은 모음(adduction)을 가졌 다. ${ }^{78}$

물리치료만 받은 그룹의 정상측 지절은 체중부하기(weight acceptance) 동안 그리고 초기 접지 기에서 대조군보다 역시 적은 굽힘을 가 졌다. 수술적으로 관리 받은 그룹에 비해, 물리치료만 받은 그룹의 손 상측은 초기 접지기, 체중부하기 시 최대 모음, 그리고 보행 시 최대 굽힘에서 상당히 적은 모음을 가졌다. 이것은 치료와 관계없이 변경 된 무릎 운동형상학은 계단 내려가기 시 $\mathrm{ACL}$ 손상 후 20년 이상 존재 한다는 것을 의미한다.78

\section{근전도}

$\mathrm{ACL}$ 결손 환자와 건강한 대조군 간에 무릎근육의 근활성도를 비교 한 결과 급성 $\mathrm{ACL}$ 결손 환자 에 대한 2 개의 연구와 불안정한 무릎을 가진 ACL 결손 환자에 대한 3 개의 연구는 대조군에 비해 넙다리 근 활성이 현저히 감소된 것이 발견 되었다. ${ }^{79} 6$ 개의 연구에서는 상당히 큰 넙다리 뒤근의 근 활성이 나타났고, 3 개의 연구에서는 대조군과 비교해서 $\mathrm{ACL}$ 결손 환자에서 근활성의 지속시간 이 연장된 것으로 나타났다. ${ }^{79}$ 이러한 결과는 증가된 넙다리뒤근의 근활성을 지지하는 결과이며, 감소된 넙다리 근육의 근활성도는 급성기와 무릎관절의 불안정성 경험이 있는 $\mathrm{ACL}$ 손상 환자에서 존재한다고 할 수 있다.79

\section{발목}

착지(landing) 시 발등 굽힘 가동범위, 무릎 전위(knee displacement), 지면 반력의 측정간 상관 관계는 확립되었으며, 이때 제한된 발등 굽 힘을 가진 사람은 무릎 굽힘 전위가 적고 큰 지면 반력을 나타내며 $\mathrm{ACL}$ 손상 위험이 더 클 수 있다.80 또한, 발등 굽힘 가동범위와 발바닥 과 복사뼈의 피부 감각이 건강한 대조군과 비교해 ACLR을 받은 참가
자에서 감소된다는 것이 밝혀졌다. ${ }^{81,82}$

ACLR 병력 유무에 따른 자가 보고식 발목과 무릎 기능 간의 상관 관계를 조사한 연구에서 ACLR 병력이 있는 대상자는 발목과 무릎기 능에 상관관계가 있는 것으로 밝혀졌다. ${ }^{59}$

\section{결 론}

현재까지 ACL 손상에 대한 예방 프로그램의 효과, 근력증가를 위한 최적의 방법, 수술 유무에 따른 효과, 그리고 신경근 훈련의 효과에 대한 합의는 매우 부족하다. 많은 의사와 치료사들은 ACL 손상 혹은 ACLR 후 생체 역학적인 관점에서 ATT를 증가시킬 수 있는 OKC 운 동방법을 지양 하여야 한다고 주장하고 있으나 이것은 실험적으로 지지 받고 있지 못하고 있다. 환자들은 일반적으로 체중부하, 관절가 동범위를 증가시키는 운동, 근력, 고유수용감각 및 균형 증진뿐만 아 니라 기능적인 운동을 포함하는 광범위한 재활을 받아야 한다. 이러 한 재활 프로그램 적용 시 중요한 요소 중 하나는 중재 시기와 유형이 다. 넙다리의 근육량 및 근력 소실이 많은 초기 재활 동안에는 통증 조절과 함께 조기 체중부하를 유도하고 $\mathrm{OKC}$ 환경에서 빠른 속도의 저항운동을 실시한다. 이후에는 낮은 폄 속도의 집중적인 등속성 운 동을 적용하는 것이 바람직하며, 이때 고려하여야 할 사항으로는 근 육에 과부하를 적용하여야 하고, 넙다리뒤근육을 동시 수축할 수 있 게 하는 것이 중요하다. 또한 ACL 손상 혹은 ACLR 후 재활 프로 그램 적용 시 재 손상이나 다른 골관절염과 같은 합병증을 예방하고 치료 의 성공적인 결과를 확인하기 위한 합의 기준을 적용하는 것이 필요 하다고 사료된다.

\section{참고 문헌}

1. Amis A, Dawkins G. Functional anatomy of the anterior cruciate ligament: fibre bundle actions related to ligament replacements and injuries. J Bone Joint Surg. 1991;73(2):260-7.

2. Boden BP, Dean GS, Feagin JA Jr et al. Mechanisms of anterior cruciate ligament injury. Orthopedics. 2000; 23(6):573-8.

3. Kobayashi H, Kanamura T, Koshida S, et al. Mechanisms of the anterior cruicate ligament injury in sports activities: a twenty-year clinical research of 1700 athletes. J. Sports Sci. Med. 2010; 9(4):669-75.

4. Quatman CE, Quatman-Yates CC, Hewett TE. A 'plane' explanation of anterior cruciate ligament injury mechanisms: a systematic review. Sports Med. 2010; 40(9):729-46.

5. Griffin LY, Albohm MJ, Arendt EA et al. Understanding and preventing noncontact anterior cruciate ligament injuries: a review of the Hunt Valley II meeting. Am. J. Sports Med. 2006; 34(9):1512-32.

6. Yanagawa T, Shelburne K, Serpas F et al. Effect of hamstrings muscle action on stability of the ACL-deficient knee in isokinetic extension exercise. Clin Biomech. 2002;17(9-10):705-12. 
7. Silvers HJ, Mandelbaum BR. ACL injury prevention in the athlete. Sports Orthopaedics and Traumatology. 2011;27(1):18-26.

8. Clancy WG Jr, Ray JM, Zoltan DJ. Acute tears of the anterior cruciate ligament. Surgical versus

conservative treatment. J Bone Joint Surg Am. 1988 ;70(10):1483-8.

9. S.R. Filbay, H. Grindem. Evidence-based recommendations for the management of anterior cruciate ligament (ACL) rupture. Best Practice \& Research Clinical Rheumatology. 2019.

10. Beynnon BD, Johnson RJ. Anterior cruciate ligament injury rehabilitation in athletes. Biomechanical considerations. Sports Med. 1996;22(1): 54-64.

11. Carter ND, Jenkinson TR, Wilson D et al. Joint position sense and rehabilitation in the anterior cruciate ligament deficient knee. Br J Sports Med. 1997;31(3):209-12.

12. Katayama M, Higuchi H, Kimura $M$ et al. Proprioception and performance after anterior cruciate ligament rupture. Int Orthop. 2004;28(5): 278-81.

13. Arnold JA, Coker TP, Heaton LM et al. Natural history of anterior cruciate tears. Am J Sports Med. 1979;7(6):305-13.

14. Yoo JH, Lim BO, Ha M et al. A meta-analysis of the effect of neuromuscular training on the prevention of the anterior cruciate ligament injury in female athletes. Knee Surg Sports Traumatol Arthrosc. 2010;18(6): 824-30.

15. Sadoghi P, Von Keudell A, Vavken P. Effectiveness of anterior cruciate ligament injury prevention training programs. J Bone Joint Surg Am. 2012;94(9):769-76.

16. Myer GD, Ford KR, McLean SG et al. The effects of plyometric versus dynamic stabilization and balance training on lower extremity biomechanics. Am J Sports Med. 2006;34(3):445-55.

17. Hewett TE, Zazulak BT, Myer GD et al. A review of electromyographic activation levels, timing differences, and increased anterior cruciate ligament injury incidence in female athletes. Br J Sports Med. 2005;39(6): $347-50$.

18. Lephart SM, Ferris CM, Fu FH. Risk factors associated with noncontact anterior cruciate ligament injuries in female athletes. Instr Course Lect. 2002;51:307-10.

19. Toth AP, Cordasco FA. Anterior cruciate ligament injuries in the female athlete. J Gend Specif Med. 2001;4(4):25-34.

20. Huston LJ, Greenfield ML, Wojtys EM. Anterior cruciate ligament injuries in the female athlete. Potential risk factors. Clin Orthop Relat Res. 2000;372(372):50-63.

21. Myer GD, Sugimoto D, Thomas $S$ et al. The influence of age on the effectiveness of neuromuscular training to reduce anterior cruciate ligament injury in female athletes: a meta-analysis. Am J Sports Med. 2013;41(1):203-15.

22. Li G, Rudy TW, Sakane M, Kanamori A et al. The importance of quadriceps and hamstring muscle loading on knee kinematics and in-situ forces in the ACL. J Biomech. 1999;32(4):395-400.

23. Pandy MG, Shelburne KB. Theoretical analysis of ligament and extensor-mechanism function in the ACL-deficient knee. Clin Biomech. 1998;13(2):98-111.

24. Steele JR, Roger GJ, Milburn PD. Tibial translation and hamstring activity during active and passive arthrometric assessment of knee laxity. The Knee. 1994;1(4):217-23.
25. Baratta R, Solomonow M, Zhou BH et al. Muscular coactivation. The role of the antagonist musculature in maintaining knee stability. Am J Sports Med. 1988;16(2):113-22.

26. Kalund S, Sinkjaer T, Arendt-Nielsen L et al. Altered timing of hamstring muscle action in anterior cruciate ligament deficient patients. Am J Sports Med. 1990;18(3):245-8.

27. Osternig LR, Caster BL, James CR. Contralateral hamstring (biceps femoris) coactivation patterns and anterior cruciate ligament dysfunction. Med Sci Sports Exerc. 1995;27(6):805-8.

28. Solomonow M, Baratta R, Zhou BH et al. The synergistic action of the anterior cruciate ligament and thigh muscles in maintaining joint stability. Am J Sports Med. 1987;15(15):207-13.

29. Walla DJ, Albright JP, McAuley E et al. Hamstring control and the unstable anterior cruciate ligament-deficient knee. Am J Sports Med. 1985; 13(1):34-9.

30. Hirokawa S, Solomonow M, Luo Z et al. Muscular co-contraction and control of knee stability. J Elect Kinesiol. 1991;1(3):199-208.

31. Shelburne KB, Pandy MG. Determinants of cruciate-ligament loading during rehabilitation exercise. Clin Biomech. 1998;13(6):403-13.

32. Imran A, O'Connor JJ. Control of knee stability after ACL injury or repair: interaction between hamstrings contraction and tibial translation. Clin Biomech. 1998;13(3):153-62.

33. Liu W, Maitland ME. The effect of hamstring muscle compensation for anterior laxity in the ACL-deficient knee during gait. J Biomech. 2000; 33(7):871-9.

34. Serpas F, Yanagawa T, Pandy MG. Forward-dynamics simulation of anterior cruciate ligament forces developed during isokinetic dynamometry. Comput Meth Biomech Biomed Eng. 2002; 5(1):33-43.

35. Gagnier JJ, Morgenstern H, Chess L. Interventions designed to prevent anterior cruciate ligament injuries in adolescents and adults: a systematic review and meta-analysis. Am J Sports Med. 2013;41(8):1952-62.

36. Postma WF, West RV. Anterior cruciate ligament injury-prevention programs. J Bone Joint Surg Am. 2013;95(7):661-9.

37. Stojanovic MD, Ostojic SM. Preventing ACL injuries in team-sport athletes: a systematic review of training interventions. Res Sports Med. 2012;20(3-4):223-38.

38. Taylor JB, Waxman JP, Richter SJ et al. Evaluation of the effectiveness of anterior cruciate ligament injury prevention programme training components: a systematic review and meta-analysis. Br J Sports Med. 2015; 49(2):79-87.

39. Onate JA, Guskiewicz KM, Marshall SW et al. Instruction of jump-landing technique using videotape feedback: altering lower extremity motion patterns. Am J Sports Med. 2005;33(6):831-42.

40. Grindstaff TL, Hammill RR, Tuzson AE et al. Neuromuscular control training programs and noncontact anterior cruciate ligament injury rates in female athletes: a numbers-needed-to-treat analysis. J Athl Train. 2006;41(4):450-6.

41. Milner CE, Fairbrother JT, Srivatsan A et al. Simple verbal instruction improves knee biomechanics during landing in female athletes. Knee. 2012;19(4):399-403.

42. Tagesson S, Oberg B, Good L et al. A comprehensive rehabilitation program with quadriceps strengthening in closed versus open kinetic chain exercise in patients with anterior cruciate ligament deficiency: a randomized clinical trial evaluating dynamic tibial translation and muscle 
function. Am J Sports Med. 2008;36(2):298-307.

43. Glass R, Waddell J, Hoogenboom B. The effects of open versus closed kinetic chain exercises on patients with ACL deficient or reconstructed knees: a systematic review. N Am J Sports Phys Ther. 2010;5(2):74-84.

44. Jewiss D, Ostman C, Smart N. Open versus closed kinetic chain exercises following an anterior cruciate ligament reconstruction: A systematic review and meta-analysis. J Sports Med (Hindawi Publ Corp). 2017;2017: 4721548 .

45. Yack HJ, Collins CE, Whieldon TJ. Comparison of closed and open kinetic chain exercise in the anterior cruciate ligament-deficient knee. Am J Sports Med. 1993;21(1):49-54.

46. Beynnon BD, Fleming BC. Anterior cruciate ligament strain in-vivo: a review of previous work. J Biomech. 1998;31(6):519-25.

47. Irrgang JJ. Modern trends in anterior cruciate ligament rehabilitation: nonoperative and postoperative management. Clin Sports Med. 1993; 12(4):797-813.

48. Mangine RE, Noyes FR. Rehabilitation of the allograft reconstruction. J Orthop Sports Phys Ther. 1992;15(6):294-302.

49. Shelbourne KD, Nitz P. Accelerated rehabilitation after anterior cruciate ligament reconstruction. J Orthop Sports Phys Ther. 1992;15(6):256-64.

50. Wilk KE, Andrews JR. Current concepts in the treatment of anterior cruciate ligament disruption. J Orthop Sports Phys Ther. 1992;15(6): 279-93.

51. Gerber JP, Marcus RL, Dibble LE et al. Effects of early progressive eccentric exercise on muscle size and function after anterior cruciate ligament reconstruction: a 1-year follow-up study of a randomized clinical trial. Phys Ther. 2009;89(1):51-9.

52. Gerber JP, Marcus RL, Dibble LE et al. Effects of early progressive eccentric exercise on muscle structure after anterior cruciate ligament reconstruction. J Bone Joint Surg Am. 2007;89(3):559-70.

53. Malempati C, Jurjans J, Noehren B et al. Current rehabilitation concepts for anterior cruciate ligament surgery in athletes. Orthopedics. 2015;38(11):689-96

54. Gerber JP, Marcus RL, Dibble LE et al. Safety, feasibility, and efficacy of negative work exercise via eccentric muscle activity following anterior cruciate ligament reconstruction. J Orthop Sports Phys Ther. 2007; 37(1):10-18.

55. Gerber JP, Marcus RL, Dibble LE et al. Early application of negative work via eccentric ergometry following anterior cruciate ligament reconstruction: a case report. J Orthop Sports Phys Ther. 2006;36(5):298-307.

56. Hortobagyi T, Barrier J, Beard D et al. Greater initial adaptations to submaximal muscle lengthening than maximal shortening. J Appl Physiol. 1996;81(4):1677-82.

57. Hortobagyi T, Dempsey L, Fraser D et al. Changes in muscle strength, muscle fibre size and myofibrillar gene expression after immobilization and retraining in humans. J Physiol. 2000;524(1):293-304.

58. LaStayo PC, Pierotti DJ, Pifer J et al. Eccentric ergometry: increases in locomotor muscle size and strength at low training intensities. Am J Physiol Regul Integr Comp Physiol. 2000; 278(5): R1282-8.

59. Hoch JM, Baez SE, Hoch MC. Examination of ankle function in individuals with a history of ACL

reconstruction. Phys Ther Sport. 2019.

60. Frobell RB, Roos EM, Roos HP et al. A randomized trial of treatment for acute anterior cruciate ligament tears. N Engl J Med. 2010;363(4):331-
42.

61. Frobell RB, Roos HP, Roos EM et al. Treatment for acute anterior cruciate ligament tear: five year outcome of randomised trial. BMJ. 2013; 346(6):\{232.

62. Wellsandt E, Failla MJ, Axe M et al. Does anterior cruciate ligament reconstruction improve functional and radiographic outcomes over nonoperative management 5 Years after injury? Am J Sports Med. 2018; 46(9):2103-12.

63. Kovalak E, Atay T, Çetin Cet al. Is ACL reconstruction a prerequisite for the patients having recreational sporting activities? Acta Orthop Traumatol Turc. 2018;52(1):37-43.

64. vanYperen DT, Reijman M, vanEs EM et al. Twenty-year follow-up study comparing operative versus nonoperative treatment of anterior cruciate ligament ruptures in high-level athletes. Am J Sports Med. 2018; 46(5):1129-36.

65. Balasingam S, Sernert N, Magnusson H et al. Patients with concomitant intra-articular lesions at index surgery deteriorate in their knee injury and osteoarthritis outcome score in the long term more than patients with isolated anterior cruciate ligament rupture: a study from the swedish national anterior cruciate ligament register. Arthroscopy. 2018;34(5): 1520-29.

66. Cox CL, Huston LJ, Dunn WR et al. Are articular cartilage lesions and meniscus tears predictive of IKDC, KOOS, and Marx activity level outcomes after anterior cruciate ligament reconstruction? A 6-year multicenter cohort study. Am J Sports Med. 2014;42(5):1058-67.

67. Filbay SR, Ackerman IN, Dhupelia S et al. Quality of life in symptomatic individuals after anterior cruciate ligament reconstruction, with and without radiographic knee osteoarthritis. J Orthop Sports Phys Ther. 2018;48(5):398-408.

68. Claes S, Hermie L, Verdonk R et al. Is osteoarthritis an inevitable consequence of anterior cruciate ligament reconstruction? A meta-analysis. Knee Surg Sports Traumatol Arthrosc. 2013;21(9): 1967-76.

69. Forkel P, Von Deimling C, Lacheta L et al. Repair of the lateral posterior meniscal root improves stability in an ACL-deficient knee. Knee Surg Sports Traumatol Arthrosc. 2018;26(8):2302-09.

70. Petrigliano FA, Musahl V, Suero EM et al. Effect of meniscal loss on knee stability after single-bundle anterior cruciate ligament reconstruction. Knee Surg Sports Traumatol Arthrosc. 2011;19(S1):S86-93.

71. Seon JK, Gadikota HR, Kozanek M et al. The effect of anterior cruciate ligament reconstruction on kinematics of the knee with combined anterior cruciate ligament injury and subtotal medial meniscectomy: an in vitro robotic investigation. Arthroscopy. 2009;25(2):123-30.

72. Mehl J, Otto A, Baldino JB et al. The ACL-deficient knee and the prevalence of meniscus and cartilage lesions: a systematic review and metaanalysis (CRD42017076897). Arch Orthop Trauma Surg. 2019.

73. Fukuda TY, Fingerhut D, Moreira VC et al. Open kinetic chain exercises in a restricted range of motion after anterior cruciate ligament reconstruction: A randomized controlled clinical trial. Am J Sports Med. 2013;41(4):788-94.

74. Lynch AD, Logerstedt DS, Grindem $\mathrm{H}$ et al. Consensus criteria for defining "successful outcome" after ACL injury and reconstruction: a Delaware-Oslo ACL cohort investigation. Br J Sports Med. 2015;49(5):33542.

75. Failla MJ, Arundale AJ, Logerstedt DS et al. Controversies in knee reha- 
bilitation: anterior cruciate ligament injury. Clin Sports Med. 2015;34(2): $301-12$.

76. Secrist ES, Freedman KB, Ciccotti MG et al. Pain management after outpatient anterior cruciate ligament reconstruction: a systematic review of randomized controlled trials. Am J Sports Med. 2016;44(9):2435-47.

77. Wang WM, Cui DP, Zhao DW et al. Gait analysis after anterior cruciate ligament reconstruction with different methods. Zhonghua Yi Xue Za Zhi. 2010;90(1):10-4.

78. Sole G, Tengman E, Grip H et al. Knee kinematics during stair descent 20years following anterior cruciate ligament rupture with and without reconstruction. Clin Biomechanics. 2016;32:180-6.

79. Shanbehzadeh S, Mohseni Bandpei MA, Ehsani F. Knee muscle activity during gait in patients with anterior cruciate ligament injury: a systematic review of electromyographic studies. Knee Surg Sports Traumatol Arthrosc. 2017;25(5):1432-42.

80. Fong CM, Blackburn JT, Norcross MF et al. Ankle-dorsiflexion range of motion and landing biomechanics. J Athl Train. 2011;46(1):5-10.

81. Wahlstedt C, Rasmussen-BarrE. Anterior cruciate ligament injury and ankle dorsiflexion. Knee Surg Sports Traumatol Arthrosc. 2015;23(11): 3202-7.

82. Hoch JM, Perkins WO, Hartman JR et al. Somatosensory deficits in post-ACL reconstruction patients: A case-control study. Muscle Nerve. 2017;55(1):5-8. 